III.

\title{
A Case of Accidental Hæmorrhage and Chronic Uræmia in which the Bacillus Proteus was Found.
}

A. Sтоокеs, Hon. Surgeon to Liverpool University Hospital, and Liverpool Samaritan Hospital for Women; and E. E. GLyns, Assistant Professor of Pathology, Liverpool University, and Pathologist to Liverpool Royal Infirmary.

A woman, 28 years of age, who had had five children and four miscarriages, was admitted to the Maternity Hospital on May 8th, 1908.

The woman had been living a hard life; her husband was alcoholic, and had been out of work all the winter. She herself had gone out charing. She was six and a half months pregnant, her last child being eleven months old. During this pregnancy she had complained of headache.

On the 30 th of $\Delta$ pril she began to lose blood per vaginam, and this continued until she was seen on May 8th by the Obstetric Assistant, Dr. Hendry, who found she had been losing a large amount of blood and that the loss was still going one; she was complaining of abdominal pain. She was blanched and restless, with a small pulse of from 110 to 120 per minute. She had a tense, tender abdominal swelling about the size of the uterus at the eighth month. The os was dilated to about two inches in diameter, the membranes intact and a head presenting.

She was sent into the Maternity Hospital, where it was found that the os was fully dilated; the membranes were ruptured, and the ehild was born spontaneously with placenta and elot. The placenta weighed $14 \mathrm{oz}$. and clot $27 \mathrm{oz}$.

The uterus contracted well after delivery and there was no post partum hæmorrhage.

I should here point out that there had been very little vaginal examination and no interference beyond the rupture of the membranes. The patient's condition made us very anxious from the first, on account of her extreme bloodlessness, feeble pulse and the suppression of urine which continued, until she died. In the first twenty-four hours she passed only two drachms of urine, although a catheter was twice used. The first specimen saved was thought to have had some fæcal contamination, being passed when the bowels were moved. It was found to be alkaline, its specific gravity was 1014, and a fæcal odour was noticed. It contained a slight amount 
of albumen; no blood was found. Urea was estimated at 1 per cent.; next day 4 ounces was passed, and on the fourth day 4 ounces. This was examined. It contained a deposit of mucus and phosphates and had no abnormal smell. A small quantity of albumen was found. Urea estimated to be 1.5 per cent. On the seventh day the same characters were observed.

The further examination was difficult as the patient had involuntary evacuations.

No bacteriological examination was made.

General cedema began in the face on the second day, and increased as time went on. It was impossible to make out the condition of the uterus on account of the swelling and tenderness of the abdomen.

On the fourth day she had syncopal attacks with twitching of the face and limbs, and she complained of pain in the abdomen. After free purgation she seemed, on the fifth, sixth and seventh days, to be improving, but the twitching, cyanosis and mental impairment increased, with vomiting and involuntary evacuations of the bowels and bladder, until she died comatose on May 19th, the eleventh day after admission.

The temperature record did not help us much; for the first three days it was above normal, the highest point being $100 \cdot 6^{\circ} \mathrm{F}$. twentyfour hours after admission. After the fifth day it was, for the most part, normal or subnormal.

To my mind, the case seemed one where a half-starved woman, with, possibly, chronic renal disease, had a very severe and continued hæmorrhage, and as the result of the insufficiency of the bloodpressure the kidneys were unable to work. I thought the case one of chronic uræmia rather than one of septic infection.

The post mortem was made by Dr. Emrys Roberts. He found a small quantity of clear fluid in the abdomen. On opening the uterus the cervix and body were covered with greenish chocolate-coloured, sloughing material, suggesting sepsis. There were laminated thrombi in the uterine veins.

The kidneys were enlarged, weighing $7 \frac{1}{2}$ ozs. each, and presented a most unusual appearance, for fully two-thirds of their cortex was the seat of numerous small anæmic infarctions, surrounded by zones of congestion. The medulla of the kidneys was only slightly affected.

The other organs were normal, except the spleen, which weighed 10 ozs.

Cultures were made from the kidneys and spleen by Dr. Roberts, who handed them to Dr. Ernest Glynn for identification. He isolated a slender, non-spore-bearing, actively motile, gram-negative, non-capsulated bacillus, which clotted and eventually peptonized milk, rapidly liquefied gelatine, and rendered sterile urine ammoniacal in 24 hours. These and the other cultural reactions 
indicated that it was the $B$. proteus vulgaris,- an organism which sometimes infects the genito-urinary tract and produces ammoniacal urine.

On microscopical examination, the kidneys showed the usual appearances of anæmic infaretion with the addition of patches of round-celled infiltration. Many of the tubules, especially secreting tubules, were completely plugged with epithelial debris and enormous masses of slender, gram-negative bacilli varying in length from 4 to $30 \mu$. These bacilli were most numerous in the necrotic areas. The condition of the blood in the vessels unfortunately could not be ascertained, owing to hæmolysis of the red corpuscles, which may have been the result of post mortem decomposition or of improper fixation.

Microscopical examination of the uterus showed acute inflammation with formation of sloughs and numerous clusters of staphylococei, which cultures demonstrated to be staphylococcus aureus.

Sections of the liver and spleen revealed nothing of importance.

The bacteriologieal and microscopical examinations demonstrate therefore that the uterus was infected with staphylococeus aurens, and the kidneys with the bacillus proteus vulgaris. The fact that the latter organism was also isolated from the spleen indicates in all probability a terminal septicæmia.

The same organism was undoubtedly, directly or indirectly, the cause of the renal infarets.

Clinically, it is most important to note (1) that the patient was suffering from partial suppression of urine when admitted into hospital, and that the condition continued until she died of uræmia; (2) that the urine was alkaline and had a foul odour.

It is unfortunate that neither the urine nor blood were examined during life, but, apart from this, there is no doubt that the renal condition was due to the bacillus proteus rulgaris.

It appears highly probable, therefore, that the accidental hæmorrhage was secondary to the bacterial infection of the kidneys.

Bacillus proteus vulgaris frequently produces cystitis and ammoniacal urine, and occasionally attacks the kidneys or is responsible for puerperal infection.

We thought this case worth recording, because $B$. proteus is one of the lesser known pathogenic bacteria, and its existence therefore is in danger of being overlooked. 